\title{
Seventy years of Chinese anthropology
}

\author{
Jijiao Zhang ${ }^{1}$ (D) $\cdot$ Yue $\mathrm{Wu}^{2}$
}

Open Access

Received: 14 December 2020 / Accepted: 14 May 2021 / Published online: 15 June 2021

(c) The Author(s). 2021

\begin{abstract}
This paper examines the 70-year history of Chinese anthropology from domestic and international perspectives since the founding of the People's Republic of China in 1949. The policy of reform and opening-up in 1978 was a turning point in Chinese anthropology. Within the 30 years before the reform and opening-up, Chinese anthropology was more or less at a 10-year standstill that was then followed by a boom influenced by the former Soviet Union. The continued development of Chinese anthropology in the 40 years after reform and opening-up can be divided into five stages based on "major events" and "internationalization." The first stage (1978-1995) can be described as a discipline reconstruction period; the second stage (1995-1999) witnessed the fast development and internationalization of Chinese anthropology; in the third stage (2000-2008), Chinese anthropology became an important discipline at home with improving international integration. The fourth stage (2009-2012) exhibited the initial formation of the discipline system and frequent international exchanges; and the fifth stage saw deepening domestic anthropology research and increasing overseas studies (from 2013 to present). In the past 70 years, and especially in the 40 years of reform and opening-up, Chinese anthropology has developed greatly in many aspects, including institution building, degree awarding, talent training, research communities establishing, conferences held at home and abroad, engagement with hotly-debated issues, and has existed with both advantages and disadvantages. All these demonstrate the characteristics of Chinese anthropology that are different from the discipline as practiced in the West.
\end{abstract}

\section{Yue $\mathrm{Wu}$}

1572727011@qq.com

Jijiao Zhang

zhjijiao@126.com

1 Institute of Ethnology and Anthropology, Chinese Academy of Social Sciences, No.6 Blg, No.27, Zhongguancun Nandajie Road, Haidian District, Beijing, China

2 University of Chinese Academy of Social Sciences, No.11 Changyu Road, Fangshan District, Beijing, China 
Keywords Chinese anthropology · Development stages · Reform and opening-up · Diversification

\section{Abbreviations}

AAA: American Anthropology Association

CUAA: China Urban Anthropology Association

CUAES: China Union of Anthropological and Ethnological Sciences

IUAES: International Union of Anthropological and Ethnological Sciences

\section{Introduction}

Anthropology, which was born in the mid-nineteenth century in the West, was translated and introduced into China in 1916. Thanks to the efforts of pioneering anthropologists, Western anthropology began to spring up in China in the 1920s, as they believed in the idea of revitalizing China with Western modern sciences. However Chinese anthropology showed distinctive Chinese features. Before the founding of the People's Republic of China in 1949, Chinese anthropology could be divided into two schools - the Southern School and the Northern School-differentiated according to different theoretical paradigms as well as the cultural experiences and backgrounds of their respective leaders. The Southern School, also known as the Chinese historical school, was mainly represented by Prof. Lin Huixiang of Academia Sinica under the influence of his American counterpart, Franz Boas. It focused its attention on traditional Chinese history and culture as a means to reconstruct the cultural history of the Chinese nation (Huang and Gong 1995). The Northern School, mainly represented by Prof. Wu Wenzao of Yenching University under the influence of British functionalism led by B.K. Malinowski and Alfred Radcliffe-Brown (He and Tang 2005), was aimed at solving practical problems at home and developing its own theoretical paradigm. Yet, both schools shared a dream of sinicizing anthropology with distinctive Chinese characteristics. And this dream still goes on today.

It should first be made clear that although anthropology and ethnology have something in common, they are fundamentally different. In China, anthropology mainly refers to the study of the entirety of humanity and culture, while ethnology focuses on the study of various ethnicities, ethnic minorities in particular. Moreover, Chinese anthropology varies widely from Western colonial anthropology in terms of research objects and academic goals.

\section{Methods}

This paper examines the 70-year history of Chinese anthropology from domestic and international perspectives since the founding of the People's Republic of China. The policy of reform and opening-up in 1978 was a turning point in Chinese anthropology that can divide its development into two phases: the early 30 years before (1949-1978) and the later 40 years after the reform and opening-up 
(1978-present). Considering that, we will examine Chinese anthropology synchronically in terms of institution building, degree awarding, talent training, organization establishing, conference holding and participating at home and abroad, hotlydebated issues, and subsequent advantages and disadvantages. In addition, we will also conclude five stages of Chinese anthropology diachronically based on "major events" and "internationalization." Therefore, we will give a comprehensive summary of the path of Chinese anthropology and get a glimpse of what it is to come.

\section{Results and discussion}

\section{Thirty years of Chinese anthropology before reform and opening-up}

The emerging period since the founding of the People's Republic of China (19491966)

After the founding of the People's Republic of China in 1949, the Ministry of Education integrated educational resources under the guidance of experts from the former Soviet Union experts and in respect to Marxism-Leninism. At that time, some regarded anthropology as a practice of colonialism since Western anthropology was utilized to serve the colonial governments. The consensus was thus reached that the so-called bourgeois disciplines like anthropology and sociology needed to be eliminated, while ethnology had a narrow escape thanks to its European continental tradition ( $Q u$ 2008). Although the name of anthropology had been abolished, some social and cultural studies were still carried out under the cover of ethnology with transformed theories and methods. Against such a background, Chinese anthropology as a branch of "Marxist anthropology," was overshadowed by ethnic studies (Ping 2017), which was mainly employed in the two nation-wide investigations- "ethnic identification" and "social and historical investigation of ethnic minorities." At first glance, such a policy might have damaged the development of anthropology, as it put up so many physical and ideological barriers. Taking a closer look, however, we can see the interdisciplinary cooperation among anthropology, ethnology, linguistics, history, and so on, which was definitely beneficial to the future development of this brand-new discipline.

To sum up, the emerging period of Chinese anthropology was characterized by the interaction between disciplinary development and political events, and with interdisciplinary cooperation bearing its first fruits. Such characteristics are undoubtedly one of the most important features of Chinese anthropology.

\section{The stagnant period of the cultural revolution (1966-1978)}

During the Cultural Revolution period (1966-1978), the Soviet model of ethnology was denounced as revisionist, and colonialism-stained anthropology could not gain a foothold in China. In this special period, both Chinese and Western anthropology were non-existent, and anthropology in China was at a complete standstill (Qu 2008). 


\section{Forty years of Chinese anthropology after the reform and opening-up}

This section discusses the 40-year development of Chinese anthropology since the reform and opening-up policy was adopted. According to "major events" and "internationalization," Chinese anthropology can be divided into the following five stages: the first stage, from 1978 to 1995, saw the reconstruction of anthropology, primarily in the setting-up of majors and research centers in universities and institutions. The second stage, from 1995 to 1999, started with the First Sociology and Anthropology Symposium at Peking University and witnessed the rapid development of Chinese anthropology. In the third stage, from 2000 to 2008, Chinese anthropology began to step into the international community. In the fourth stage from 2009 to 2012, as the discipline construction and international influence reached a new level, the achievements of Chinese anthropology began to be recognized internationally. From 2013 to the present, Chinese anthropology has been expanding its research to overseas studies in all aspects.

\section{The discipline reconstruction period (1978-1994)}

In 1978, the Central Committee of the Communist Party of China held a "National Science Conference" in Beijing, which signified that China's scientific and technological work had ushered in a scientific "golden age" after "ten years of turmoil." At the conference, some scholars put forward the proposal to re-establish Chinese anthropology, which won widespread applause of ethnologists and sociologists at home.

Chinese anthropology developed at a surprising pace thanks to favorable policies, particularly in terms of institutional set-up and talent training. In 1981, Sun Yat-sen University in Guangzhou, Guangdong province was the first to restore the department of anthropology within China. With Prof Liang Zhaotao as the head of the anthropology department (Zhou 2016), Sun Yat-sen University set up two undergraduate majors in ethnology (later renamed anthropology) and archaeology, and it also began to enroll graduate students and $\mathrm{PhD}$ candidates in cultural anthropology. ${ }^{1}$ Other universities and colleges followed suit. Xiamen University of Fujian province set up master's programs in cultural anthropology in 1982, and the Anthropology Institute as well as the Department of Anthropology in 1984 (Shi and Dayu 1993). In 1987, Yunnan University established an anthropology major (albeit under the Department of History). ${ }^{2}$

In June and August 1980, the Preparatory Group of the Chinese Anthropological Society and its Preparatory Committee were formally established. In 1981, the "First National Anthropology Symposium" was held at Xiamen University on

\footnotetext{
${ }^{1}$ The Department of Anthropology of Sun Yat-sen University began recruiting undergraduate students in 1981. Zhang Jijiao, one of the authors, was the second undergraduate student (1981) after the restoration of the department. In terms of major setup, the department divided anthropology into four branches: archaeology, ethnology (cultural anthropology), linguistic anthropology, and physical anthropology, according to the academic tradition of the American Historical School. At that time, if non-anthropological undergraduates were admitted to the master's programs, these four branches were compulsory courses for them.

${ }^{2}$ The college of Ethnology and Sociology, Yunnan University: http://www.msxy.ynu.edu.cn/:
} 
the theme of "the status and role of anthropology." Also that year, the Chinese Anthropological Society was founded, and Prof. Chen Guoqiang served as the first chairman. Since then, the Chinese Anthropological Society has held numerous academic seminars, and published several conference proceedings. ${ }^{3}$ The Society, as an important academic group in the Chinese anthropology circle, was the incubator for innovative ideas and international exchanges. Talented scholars emerged accordingly. Even now, the Chinese Anthropological Society remains committed to diversified academic exchanges in ways that connect scholars at home and abroad and facilitate disciplinary development.

In 1984, the "International Symposium on Anthropology and 60th Anniversary of Sun Yat-sen University" was held in Guangzhou on the theme of "the characteristics of southern Chinese culture." (Ji 1985) As the first international anthropological conference in China, this symposium greatly promoted exchanges between China and other countries and quickened the discipline restoration in some way.

At the end of 1989, the "First International Symposium on Urban Anthropology" was held in Beijing. ${ }^{4}$ This meeting offered a platform for scholars to exchange their ideas, present their achievements and transmit information, thus making urban anthropology part of the Chinese social sciences community (Zhang 1990). In June 1992, the China Union of Anthropological and Ethnological Sciences was formally established, and in 1993 it became a member of the International Union of Anthropological and Ethnological Sciences (IUAES) (Wang 1993).

In the discipline reconstruction period, Chinese anthropology was running rather smoothly. Yet some outdated issues and methods loomed as hindrances due to the former standstill of the discipline. Luckily, the isolation of Chinese anthropology did not last long (Harrell 2001). From 1978 to 1994, Chinese anthropology has been dedicated to introducing Western anthropological theories and constructing new local theory, though traditional issues and methods were still in fashion and the connection with international society was still weak. In short, Chinese anthropology during this period still centered on traditional research with a growing international orientation.

\section{The domestic growth and internationalizing period (1995-1999)}

In the discipline reconstruction period, Chinese anthropology gathered certain research experience with its own characteristics. In 1995, the "Advanced Seminar on Social \& Cultural Anthropology" marked a historical turning point in the

\footnotetext{
${ }^{3}$ For example, "The second National Symposium on Anthropology" was held in Shanghai from January 8 to 12,1983 , on the theme of "Anthropology and the Construction of Two Civilizations." In October 1985, "The third National Symposium on Anthropology" was held in Chengdu with the theme of "Anthropology and Application." In 1987, "The fourth National Symposium on Anthropology" was held in writing, on the theme of "Scientific Research, Teaching and Survey of Chinese Anthropology in Recent Years." In March 1993, "The Fifth National Symposium on Anthropology" was held again in writing, with the theme "Development of Chinese Anthropology."

${ }^{4}$ Zhang Jijiao, one of the authors, worked in the Institute of Ethnology of the Chinese Academy of Social Sciences at that time, and was transferred from the research office to the scientific research office to prepare "the First International Symposium on Urban Anthropology."
} 
development of Chinese anthropology, heralding a new period of comprehensive and accelerated development (Zhou 1995). In the same year, Prof. Fei Xiaotong proposed that Chinese anthropology, ethnology, and sociology had best share a joint development path, each in its proper place and coexisting in harmony (Zhou 2012). As an independent discipline, Chinese anthropology finally came in the foreground.

In June 1995, the "First Advanced Seminar on Chinese Social \& Cultural Anthropology," hosted by the Institute of Social Anthropology of Peking University, was held in Beijing. This meeting brought together well-known anthropologists and sociologists from home and abroad, as well as scholars and teachers from universities in China. Such a large-scale seminar stimulated academic exchanges, and gave young anthropologists a better understanding of international cutting-edge knowledge in anthropology and other fields. Amid the equal and harmonious discussions, young and senior scholars exchanged their insights, challenged traditional ideas, and developed new theories. 5

Relatively speaking, the establishment of anthropological institutions in this stage was quite low-key in comparison with what was accomplished in the first, as its focus fell mainly on the renaming of original institutions and the establishment of sub-discipline institutions of anthropology. For example, in 1995, the Institute of Ethnology of the Yunnan Academy of Social Sciences set up the Film Center of Visual Anthropology. In 1996, the Chinese Society of Literary Anthropology was established; and in 1998, the Institute of Ethnology in Guangxi Institute of Ethnology was renamed as the Institute of Ethnology and Anthropology.

An independent discipline requires a complete degree-awarding system and sophisticated talent training programs. Only in such a way would Chinese anthropology gain recognition at the national level. In 1997, the Academic Degrees Committee of the State Council decided to change the subject "cultural anthropology," which was originally subordinate to ethnology (first-level discipline), to "anthropology," a second-level discipline under sociology (first-level discipline). This was an encouragement for the independent development of anthropology and for correcting the long-time confusion between anthropology and ethnology. As for talent training, some universities, such as Peking University (1998) and Yunnan University (1996, 1998), began to set up master's and doctoral programs, but it was still in the initial stage with low enrollment rates. Besides, some colleges and universities also began to train all-around anthropology talents through various

\footnotetext{
${ }^{5}$ Since then, the seminar has been held several times. From 5 to 12 January 1997, "The second Advanced Seminar on Social \& Cultural Anthropology" was held at Peking University, allowing scholars from different symposia to discuss the topic of "The construction and localization of Chinese anthropology." From 15 June to 5 July 1998, "The third Advanced Seminar on Social \& Cultural Anthropology" was also held at Peking University, and coincided with the centenary of Peking University; an International Lecture Series "twenty-first Century: Cultural Consciousness and Intercultural Dialogue" was also held. This seminar paid special attention to the issue of how Chinese anthropology, ethnology and sociology share a joint development path, each in its proper place and coexisting in harmony. From 23 June to 2 July 1999, the "Fourth Advanced Seminar (International Conference) on Social \& Cultural Anthropology," co-sponsored by Peking University and Yunnan University, was held in Kunming, Yunnan Province. The theme of this conference was "Ethnosociology," "social and cultural anthropology," and "Chinese ethnic studies."
} 
means. For example, in 1998, Sun Yat-sen University specially set up an educational-practice base of the Department of Anthropology; in 1999, Yunnan University jointly organized several advanced courses in visual anthropology with German scholars, and trained a large number of outstanding talents in Chinese visual anthropology. In a word, colleges and universities set their sights on anthropology, which was of great benefit to cultivate a new generation of anthropological talents.

During this period, "anthropological localization" gained more and more momentum. In September 1999, the "International Symposium on the Localization of Anthropology" was held at Guangxi University for Nationalities. The seminar was attended by more than 70 scholars from all over China and from the United States, Britain, France and Japan. During the meeting, the delegates talked about the theories, methods, and practices of anthropological localization (Gao and Zou 1999).

Though earlier hot topics had been the subject for years, new research issues emerged at the turn of the century, particularly in various branches of anthropology. Moreover, with the increasing number of foreign translation works, the gap between Chinese and Western anthropology was narrowing. However, this period still saw a low level of internationalization, limited international communication, and a relatively small number of international conferences. The above challenges called for Chinese anthropology to take urgent action to move to the next stage.

In a word, Chinese anthropology opened a new chapter and entered the stage of rapid development, marked by the holding of the "Advanced Seminar on Social \& Cultural Anthropology" in 1995. The research institutions were continually springing up, though in a small number. With the further development of master's and doctoral programs, each branch of anthropology as an independent discipline went in the right direction based on the previous discipline reconstruction, local research results, and Western experiences.

\section{A domestic key discipline and increasing internationalization period (2000-2008)}

The early twenty-first century witnessed a spurt of progress in Chinese anthropology as it has made initial achievements since discipline reconstruction. As the talent training system continuously improved, Chinese anthropology became more integrated into the global academic world. Marked by the "Inter-Congress of the International Union of Anthropological and Ethnological Sciences" in Beijing in 2000, Chinese anthropology has gradually proceeded hand-in-hand with other countries. In 2001, the anthropology major at Sun Yat-sen and Peking Universities was approved by the Ministry of Education as a "national key subject," which meant the long-time reconstruction of Chinese anthropology was welcomed nationwide, and anthropology was recognized by those in the national social sciences.

In July 2000, the "Inter-Congress of IUAES was hosted by the China Urban Anthropology Association" (CUAA) in Beijing on the theme of "urban ethnic

\footnotetext{
${ }^{6}$ Zhang Jijiao, one of the authors, was then deputy secretary-general of the China Urban Anthropology Association and assistant secretary-general of the Preparatory Committee for the 2020 Inter-Congress of the International Union of Anthropological and Ethnological Sciences.
} 
culture: preservation and interaction." ${ }^{, 6}$ More than 340 experts and scholars from 46 countries attended this congress which was organized in six series and a variety of sub-topics under each major topic. The congress also received more than two hundred visual anthropology works which appealed to a wide audience at home and abroad. In all, this congress represented great progress in Chinese anthropology that was quickly going global with its own academic achievements. ${ }^{7}$ Chinese scholars, in fact, had participated in many international congresses (1983, 1988, 1993, and 1998) before, however the 2000 Inter-Congress was an exciting signature that Chinese anthropology has become one of the organizers in the global anthropological circle.

Moreover, driven partly by the 2000 Inter-Congress, the number of international conferences held in China was expanding. With increasingly active academic exchanges, these conferences demonstrated that Chinese anthropology had gone far beyond China to all corners of the world. In December 2001, "the International Conference on Sustainable Urban Development in the 21st Century and Commemoration of the Centenary of Chinese Anthropology" was held at Sun Yat-sen University. The conference featured two major themes: urban development in the twenty-first century and anthropological development in the twenty-first century (Mei 2002). More than 150 anthropologists, many of them full of ideas, from all over the world participated in the conference. At the conference, how Chinese anthropology could keep developing and where it should go in the twenty-first century remained a hot topic considered by many scholars, and the fields of urban and applied anthropology were of particular concern. More importantly, this period built up the foundation for the next century of Chinese anthropology, so as to align with international standards. In 2007, the Chinese delegation attended the 106th annual meeting of the American Anthropology Association (AAA), and both agreed to hold the "Chinese-American Anthropology and Ethnology Advanced Forum" in China in 2009, which offered a good opportunity for Chinese and American anthropologists to promote academic exchanges.

In terms of institution building, some comprehensive universities established a number of anthropology institutes, such as the Institute of Anthropology, at Renmin University of China (2003), and the Institute of Social and Cultural Anthropology, at Nanjing University (2005). At the same time, some colleges and universities also set up a series of institutes based on different branches of anthropology. For example, Sun Yat-sen University set up the Historical Anthropology Research Center (2001), the Health and Human Development Center (2002), and the Tourism Anthropology Research Center at Xiamen University (2004). As for the awarding of degrees and the training of talent in this period, undergraduate and master's enrollment levelled off but doctoral training gathered momentum, as seen at Renmin University of China (2001), Xiamen University

\footnotetext{
${ }^{6}$ Zhang Jijiao, one of the authors, was then deputy secretary-general of the China Urban Anthropology Association and assistant secretary-general of the Preparatory Committee for the 2020 Inter-Congress of the International Union of Anthropological and Ethnological Sciences.

${ }^{7}$ After the meeting, the China Urban Anthropology Association edited and published an English anthology: China Urban Anthropology Association(ed), Metropolitan Ethnic Cultures: Maintenance and Interaction, Beijing: Academy Press, 2003.
} 
(2003) and so on. With an improved high-level talent training system in China, the conditions were ripe for Chinese anthropology to expand further.

At the turn of the century, the 2000 Inter-Congress of IUAES marked Chinese anthropology's entrance into a new stage where it could advance in parallel with international peers. As many subdisciplines of anthropology thrived at an astonishing pace, confidence in the discipline was also growing. During this period, the hot topic of anthropology shifted gradually from traditional issues and localization research to internationalization and practical problems, with an emphasis on applied research in China. Bearing in mind the development of Chinese anthropology, we must admit its weakness, that is, the relatively low-level academic internationalization. Faced with reality, how to make Chinese anthropology present itself to the world and rank among the world's best are still open questions for Chinese anthropologists.

\section{The domestic-discipline-system shaping and international-exchange-enhancing period (2009-2012)}

After a century of efforts, Chinese anthropology finally formed its own characteristics, rather than blindly following Western ideas as it had once done. At the turn of the century, Chinese anthropology made progress in expanding its global presence, reaching good results in domestic and international academic research, and achieving huge breakthroughs in theoretical innovations. All these contributed to international recognition by its counterparts in the world.

"The 16th IUAES World Congress" was held in July 2009 with the general theme of "Humanity, Development, Cultural diversity," in Kunming, Yunnan, at the campus of Yunnan University and Yunnan Minzu University. ${ }^{8}$ Five keynote speeches and 14 distinguished lectures were delivered by world renowned scholars at the congress. The number of participants soared to a record level-about 5000 scholars and students from over 116 countries and regions of the world attended the Congress. In addition to the opening and closing addresses, the Congress also held 239 academic panels with more than 5000 paper abstracts, 6 cultural exhibitions, 5 study tours and 23 films. In detail, the 239 panels explored various issues related to world anthropology and ethnology and were presented on 36 subdisciplines. The cultural exhibition, film festival, and study tours all showcased the latest Chinese anthropology and ethnology research results with rich material, photographs, and detailed data, attracting many participants of the Congress (Zhang 2006). At the closing ceremony, the Kunming Declaration was drafted by the China Union of Anthropological and Ethnological Sciences (CUAES) based on the consensus reached during the Congress, and was passed at the general meeting of all members. As a significant event for China, the 16th IUAES World Congress was welcomed by scholars at home and abroad in recognition of the sustained contributions of Chinese anthropology.

\footnotetext{
${ }^{8}$ Zhang Jijiao, one of the authors, was then deputy secretary-general of the China Union of Anthropological and Ethnological Sciences and deputy secretary-general of the Preparatory Committee for the 16 th World Congress of the IUAES, and participated in the whole process of bidding and preparing for the Congress.
} 
The international academic conferences, with their advantages, were playing an increasingly important role in inter-cultural communications and became a window for other countries to get to know China. In August 2010, the CUAES held "the First Joint Meeting of Heads of Chinese Anthropology and Ethnology" at Sun Yatsen University. This conference mainly discussed the plan of the 12th Five-Year Plan and the direction of Chinese anthropology and ethnology research, that is, popularization, generalization and improving people's well-being, and striving to build Chinese anthropology into a national-level discipline (Huang and Liu 2010). Since then, the annual joint meeting has become a base camp for Chinese anthropologists to exchange ideas on hot issues, and especially for the leaders to deliberate over the questions vital for discipline development. Held in Beijing in October 2010, "The First Asian Anthropology and Ethnology Forum," allowed senior anthropologists with years of practice and research, to discuss Asian anthropological and ethnological issues, and the younger generation to actively share their latest academic research. ${ }^{9}$

To sum up, the 16th IUAES World Congress was indeed a landmark of this period, and its significance was not only in the early preparation work of the conference but also in the later review and summary sections, which further improved the international academic level of Chinese anthropology. Therefore, with the increasing internationalization, Chinese anthropology has taken a greater role on the world academic stage. However, the other side of Chinese anthropology in the globalization era should also be noted- studies on the whole international community from an anthropological perspective were scarce and displayed a lack of breakthroughs. Chinese anthropologists should keep in mind the lag in discipline development, and step up their effort to do some overseas studies to narrow the gap.

In short, marked by the 16th IUAES World Congress in 2009, the achievements and contributions of Chinese anthropology were welcomed and recognized by international counterparts, and occupied a certain place on the world stage. Domestically, Chinese scholars strengthened disciplinary construction in all aspects with the purpose of "establishing a first-level discipline of anthropology." In addition, with the increasing international influence, branches of anthropology in China began to develop toward the direction of internationalization with a large quantity of achievements.

\section{The deepening domestic research and increasing overseas investigation period (2013- present)}

Throughout this decade, the discipline system of Chinese anthropology has developed step by step toward maturity. The earlier branches of anthropology harvested research results, while new branches emerged in accordance with the times and social issues. Moreover, a growing number of Chinese anthropologists had their voices heard in the international community.

\footnotetext{
${ }^{9}$ Source: Institute of Ethnology and Anthropology of Chinese Academy of Social Sciences- First Asian Anthropology and Ethnology Forum in Beijing. Web site: http://iea.cass.cn/content-BA0810-201011 0816490268868.htm.
} 
In 2013, the "Comprehensive Survey of Economic and Social Development in China's Ethnic Minority Areas at the beginning of the $21^{\text {st }}$ Century" was conducted by the Institute of Ethnology and Anthropology of the Chinese Academy of Social Sciences. On the one hand the survey showed a growing combination of anthropological studies and practical social issues, which helped anthropologists use their expertise to serve reality and contribute to government policies while promoting the overall academic level. On the other hand, by combining the Belt and Road Initiative with the overseas studies of anthropology, this survey carried out an allround and multi-level investigation of cross-border ethnic groups and provided research material for the further development of the Belt and Road Initiative. Both proved that serving the country with expertise was favorable to anthropology as a discipline and society as a whole.

After the Belt and Road Initiative was put forward in 2013, Chinese overseas ethnography seized the opportunity to improve discipline construction and build relevant institutions in the hope of being compatible with world academic standards. In April 2014, the journal World Ethno-National Studies provided a column for "overseas ethnography." In April 2014, the Overseas Cultural Research Committee of the China Union of Anthropological and Ethnological Sciences was set up and held the "Seminar on Cultural Exchange and Overseas Research." The scholars at the meeting debated on the two major topics of "overseas research" and "cultural interaction and cross-cultural communication research."10

The previous overseas studies mainly focused on Han Chinese immigrant research, but little investigation was carried out on overseas ethnic minorities. Furthermore, it was usually conducted by individual scholars rather than undertaken by team coordination. With the influence of overseas ethnography and internationalization, China began to pay more attention to emigrated ethnic minorities. In April 2015, the major project of the National Social Science Foundation "Research on Ethnic Minority Overseas Chinese" was officially approved. The project mainly studied the overseas ethnic minorities and their descendants under the principle of "pluralistic and integrated pattern" in the new era but from a higher level, a wider perspective, and a broader scope (Ding et al. 2015). At this stage, the overseas ethnographic research achieved many breakthroughs in research achievements, scopes, and subjects.

In many ways, Chinese anthropology has gone beyond the above four stages and entered a new period of international comprehensive development. Moreover, the overseas research, supported by the Belt and Road Initiative, built a closer relationship through communication with locals in the countries along the route. That's exactly how China proposes to live together in peace with other countries and conduct studies to promote mutual development, which is fundamentally different from the Western "colonial" overseas investigation and research in anthropology. To achieve this end, Chinese anthropology has to combine theoretical research with

\footnotetext{
${ }^{10}$ Source: China Social Sciences Network- [Academic Conference] China Union of Anthropological and Ethnological Sciences, Overseas Cultural Research Committee Establishment Conference and CrossCultural Exchange and Overseas Cultural Research Symposium. Web site: http://www.cssn.cn/shx/shx_ xsdt/201405/t20140506_1149603.shtml
} 
social practice as a means to serve the people, the community, and the country, which is the next step yet to come.

In all, Chinese anthropology entered the globalization age by launching the "Comprehensive Survey of Economic and Social Development in China's Ethnic Minority areas in the early 21st Century" in 2013 along with overseas investigations along the Belt and Road. To strengthen overseas ethnography studies, Chinese anthropology focuses on localization and on viewing foreign countries from the perspective of China, on the one hand. On the other hand, it is expanding international influence and reflecting its own development as well. With rapid social transformation, the community is changing each and every passing day, and the same is true with anthropology. The aim of "localization" in anthropological research can contribute to the building of a well-off society and ethnic equality and unity in China. In addition, people in the twenty-first century live in an inter-related "global village," in which capital, culture and labor move freely across the globe. That allows us to better understand each other through trans-national studies.

\section{Conclusion}

Chinese anthropology played a historical role in national salvation 70 years ago, then came to the study of localization, internationalization, and overseas research, which are still ongoing today. Each stage of Chinese anthropology embodied the painstaking efforts and wisdom of anthropologists of earlier generations, while presenting different characteristics under different social and historical backgrounds.

In the past 70 years, Chinese anthropology enjoyed the characteristics of both localization and internationalization-from the re-investigation of traditional subjects and the initial research of new subjects in the period of discipline reconstruction, to the expanding of academic institutions and personnel training, to the increasing of internationalization and international conferences, and to the study of various ethnicities at home and abroad. As more and more Chinese scholars went abroad, the study of localization and internationalization found in Chinese anthropology became a hot topic.

After decades of discipline development, Chinese anthropology has found the right direction in a relatively short time compared with the West. As the institution-building and talent-training system came to near perfection, anthropology in China gained some international influence, and will undoubtedly continue to make great achievements. Besides international and domestic research, people's well-being and the development of community have always been the central and integral features of Chinese anthropology over the past 70 years. These unique characteristics that are different from those of the West are what Chinese anthropology is all about. However, in terms of well-known anthropological theories, Chinese anthropology still lags behind in comparison with the West; and as for discipline classification, anthropology in China is still a secondary subject under "sociology," and cultural anthropology is under "ethnology." Therefore, overcoming these is still an important task for anthropologists today.

Acknowledgements Not applicable. 
Authors' contributions Ms. Yue Wu conducts the research and writing. Dr. Jijiao Zhang is a major contributor in writing and research plan. All authors read and approved the final manuscript.

Funding Not applicable.

Availability of data and materials Not applicable.

\section{Declarations}

Ethics approval and consent to participate Not applicable.

Consent for publication Not applicable.

Competing interests We have no competing interests.

Open Access This article is licensed under a Creative Commons Attribution 4.0 International License, which permits use, sharing, adaptation, distribution and reproduction in any medium or format, as long as you give appropriate credit to the original author(s) and the source, provide a link to the Creative Commons licence, and indicate if changes were made. The images or other third party material in this article are included in the article's Creative Commons licence, unless indicated otherwise in a credit line to the material. If material is not included in the article's Creative Commons licence and your intended use is not permitted by statutory regulation or exceeds the permitted use, you will need to obtain permission directly from the copyright holder. To view a copy of this licence, visit http:// creativecommons.org/licenses/by/4.0/.

\section{References}

Ding, Hong (丁宏) \& Li, Rudong (李如东) \& Hao, Shiyuan (郝时远), et al. 2015. 国家社科基金重大项 目“少数民族海外华人研究”开题实录 (An Introduction to the National Social Science Foundation's Major Project “Study on Ethnic Minority Overseas Chinese"), 广西民族大学学报(哲学社会科学版), Journal of Guangxi University for Nationalities (Philosophy and Social Sciences Edition). 6: 47-58.

Gao, Chong (高崇) \& Zou, Qiong (邹琼). 1999. 从本土走向全球的中国人类学 (Chinese Anthropology from Native to Global). 广西民族大学学报, Journal of Guangxi University for Nationalities. ,84 49-52.

Harrell, Stevan. 2001. The anthropology of reform and the reform of anthropology: anthropological narratives of recovery and progress in China. Annual Review of Anthropology 30 (1): 139-161. https://doi.org/1 0.1146/annurev.anthro.30.1.139.

He, Guoqiang (何国强) \& Tang, Kaixun (唐凯勋). 2005. 析中国民族学北派和南派的学术倾向一一吴文 藻、杨成志为例(On the Academic Tendency of the Northern and Southern Chinese Ethnology - Taking Wu Wenzao and Yang Chengzhi as Examples). 思想战线, The Ideological Front, 5: 132-140.

Huang, Shuping (黄淑娉) \& Gong, Peihua (龚佩华). 1995. 文化人类学理论方法研究(Study on the Theory and Methods of Cultural Anthropology). 广州:广东教育出版社, 421.

Huang, Jin (黄锦) \& Liu, Chuming (刘初明). 2010. 首届中国人类学民族学学科负责人联席会议综述 (A Review of the First Joint Meeting of Heads of Chinese Anthropology and Ethnology in China). 广西民 族大学学报(哲学社会科学版), Journal of Guangxi University for nationalities (Philosophy and Social Sciences Edition), 6: 94-97.

Ji, Wen (纪闻). 1985. 中山大学人类学学术讨论会纪略(History of the Anthropology Symposium of Sun Yat-sen University). 民族研究, Ethno-national Studies, 3: 3-64.

Mei, Fangquan (梅方权). 2002. 21世纪都市可持续发展暨中国人类学百年国际学术研讨会在我校隆重召 开(The International Symposium on the International Conference on Sustainable Urban Development in the 21st Century and Commemoration of the Centenary of Chinese Anthropology). 中山大学学报(社会 科学版), Journal of Sun Yat-sen University (Social Sciences Edition), 150.

Ping, Song. 2017. Anthropology in China today. Asian Anthropology 16 (3): 228-241. https://doi.org/10.1 080/1683478X.2017.1356573. 
$\mathrm{Qu}$, Mingan (篗明安). 2008. 当代中国文化人类学(Contemporary Chinese Cultural Anthropology), 昆明:云 南出版集团公司、云南人民出版社.

Shi, Yilong (石奕龙) \& Dayu (大禹). 1993. 人类学家陈国强教授 (The Anthropologist Prof. Chen Guoqiang). 广西民族学院学报(哲学社会科学版), Journal of Guangxi University for Nationalities (Philosophy and Social Sciences Edition), 1.

Wang, Shuling (王淑玲). 1993. 中国都市人类学会第一届全国学术讨论会综述 (Summary of the First National Symposium of the Chinese Urban Anthropology Association). 民族研究, Ethno-National Studies, 5(05):102-106.

Zhang, Shuyun (张书云). 1990. 第一届都市人类学国际会议在北京召开(The First International Conference on Urban Anthropology Held in Beijing). 城市问题,Urban issues, 38.

Zhang, Jijiao (张继焦). 2006. 当今国际人类学民族学的热点议题和发展动态(Current Hot Issues and Developments in International Anthropology and Ethnology). 中央民族大学学报(哲学社会科学版), Journal of Minzu University of China (Social Sciences Edition), 2: 32-39.

Zhou, Xing (周星). 1995. 社会·文化人类学高级研讨班获得初步成功(The Initial Success of Advanced Seminar on Social and Cultural Anthropology of Peking University has achieved initial success). 民俗研 究, Folklore Studies, 3(03): 103-104.

Zhou, Daming (周大鸣). 2012. 怀念梁钊蹈先生(Reflections on the Orientation of Anthropology). 广西民族 大学学报(哲学社会科学版), Journal of Guangxi University for Nationalities (Philosophy and Social Sciences Edition), 1: 79-83.

Zhou, Daming (周大鸣). 2016. 怀念梁钊蹈先生(I Miss Mr. Liang Zhaotao). 广西民族大学学报(哲学社会科 学版), Journal of Guangxi University for Nationalities (Philosophy and Social Sciences Edition), 6: 50-51.

\section{Comments}

Publisher's Note Springer Nature remains neutral with regard to jurisdictional claims in published maps and institutional affiliations. 